\title{
Research Paper \\ Comparing the efficacy of training social-emotional skills and training social problem solving on social competence in female single parent, second period high school students
}

\begin{abstract}
Fatemeh Mokarram$^{1}$, Reza Kazemi ${ }^{2}$, Somayeh Taklavi ${ }^{2}$
1. Ph.D Student Psychology, Department of Psychology, Ardabil Branch, Islamic Azad University, Ardabil, Iran. 2. Assistant Professor, Department of Psychology, Ardabil Branch, Islamic Azad University, Ardabil, Iran.

Citation: Mokarram F, Kazemi R, Taklavi S. Comparing the efficacy of training social-emotional skills and training social problem solving on social competence in female single parent, second period high school students. J of Psychological Science. 2021; 20(105): 1651-1665.
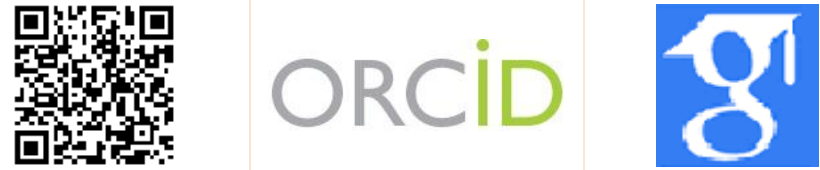

URL: https://psychologicalscience.ir/article-1-1363-fa.html

$\underline{10.52547 / J P S .20 .105 .1651}$
\end{abstract}

\section{A R T I C L E I N F O A B S T R A C T}

\section{Keywords:}

Social-Emotional skills, social problem solving, social competence,

Students, Single parent

Received: 06 Aug 2021 Accepted: 01 Sep 2021 Available: 22 Nov 2021
Background: Social competence refers to an individual's ability to do things related to his or her personal independence and social responsibilities, leading to normal social growth and the establishment of positive and constructive relationships. Emotional-social skills training plays an important role in feeling more socially competent and efficient in the day-to-day responsibilities and life challenges of single-parent girls. Research has shown that social problem-solving training increases social competence in adolescence and adulthood.

Aims: The aim of this study was to compare the effectiveness of Social-Emotional skills training and social problem-solving training on social competence of single-parent female students in the second year of Sarab high school.

Methods: The present study is a quasi-experimental study with a pretest-posttest design with a control group. The statistics of the present study include all female high school students who were studying in the academic year 2019-2020. The research sample of 45 students was selected by multistage cluster sampling method and randomly assigned to two experimental groups and one control group. The sample individuals completed the social competency questionnaire of Felner, Lease \& Phillips (1990) first as a pre-test stage and after 12 sessions of Social-Emotional skills training (Sadri Damirchi et al, 2009) and 10 sessions problem-solving training (Montazer et al, 2020) of 90-minute as a group for a group. Experiments were re-evaluated in the post-test phase of all three groups. Data analysis was performed by univariate analysis of covariance using SPSS-24 software.

Results: The results of this study showed that social-emotional skills training and social problem solving increased the social competence of effective single-parent female students ( $\mathrm{p}<0.05)$. On the other hand, there was no significant difference in the effectiveness of social-emotional skills training and social problem solving in the social competency variable $(\mathrm{P}<0.05)$.

Conclusion: Teaching adolescents' socio-emotional skills and social problem-solving skills leads to the formation of social interactions between him and the outside world, the management of emotions, and thus the increase and improvement of a person's social competence. For this purpose, it is necessary for specialists and family psychologists to provide training in this field to students and their parents.

* Corresponding Author: Reza Kazemi, Assistant Professor, Department of Psychology, Ardabil Branch, Islamic Azad University, Ardabil, Iran.

E-mail: dr_reza.kazemi@yahoo.com

Tel: (+98) 4533728020

2476-5740/ (C) 2021 The Authors. This is an open access article under the CC BY-NC-ND license

(https://creativecommons.org/licenses/by-nc/4.0/). 


\section{Extended Abstract}

\section{Introduction}

Social changes over the past decades have led to changes in the context of families and the formation of various forms of family and new lifestyles. One of the most important of these are single-parent or single-parent families, the number of which is increasing in today's society (Van Gasse \& Mortelmans, 2020). Single-parent or single-parent families are families with an imperfect and ambiguous structure that are formed for various reasons. In single-parent families, usually only one parent takes full responsibility for the life and care of the children. Decreased formal marriage, cohabitation without marriage, excessive individualism, tendency to divorce, and simplification of divorce formalities are among the main reasons for the emergence and increase of single-parent families in today's societies (Brady, 2011).

One of the variables that can affect single-parent families is social competence (Kessner and McKenry, 2001). Social competence is essential in adolescents studying (Azuka-Obieke, 2013). All students face obstacles and problems in life and need to learn various skills, including social competence, to overcome them (Banerjee, 2016). This issue becomes more important when rapid developmental changes in children, such as rapid hormonal changes due to puberty, cause severe internal tensions and disruption of interpersonal relationships (Sani, Mohammadzadeh, Jahangirmehr, Mambo and Pour, 2017). Social competence is defined as an individual's abilities and capabilities in personal independence and social responsibility (Hosokawa \& Katsura, 2017). In fact, social competence is known as interpersonal, communication and interaction skills in relation to others or emotional, practical and emotional intelligence (Stewart et al., 2018).

One of the ways that can help people feel more competent and efficient in daily responsibilities and life challenges is teaching emotional-social skills (Gooding, 2011). Emotional-social skills mean that the adolescent manages the behaviors that lead to the formation of social interactions between him and the outside world (such as starting and maintaining friendly relationships with peers and adults, cooperative behaviors and cooperation) as well as management. Master your emotions and feelings (such as managing aggression and conflict, discipline, and responsiveness) and achieve a change in your sense of skill and value (Abrahams et al., 2019).

On the other hand, failure and successful adaptation to the social environment also require a set of problem-solving skills that cannot be measured by conventional intelligence tests or personality tests (Mefoh, Nwoke, Chukwuorji \& Chijioke, 2017). Social problem solving is a cognitive-behavioral and emotional process that is an important key in managing emotions, psychological well-being and increasing social competence. The social problemsolving model was first introduced by D'Zurilla, Nezu \& Maydeu-Olivares (2002) and is one of the most comprehensive social problem-solving models. According to this view, social problem solving is a multidimensional interactive process that consists of two relatively independent components of problem orientation and problem-solving styles (Malouff, Thorsteinsson \& Schutte, 2007).

In general, it can be said that parents in single-parent families often suffer from stress due to multiple roles, especially when they take on two or more different and opposite roles at the same time, and this problem leaves the family with problems. It faces more economic issues and this stress and economic pressure is a risk factor for health and tendency to behavioral problems in the children of these families (Stack \& Meredith, 2018; Collings et al., 2014). Despite much research on the harms of single-parent families, there are still many unknown aspects of these families and their children that need to be investigated. Many studies in this field have been done quantitatively and sparsely. Therefore, considering the importance and sensitivity and risk of single-parent families, especially their daughters; The aim of this study was to compare the effect of emotional-social skills training and social problemsolving training on social competence of singleparent female students. 


\section{Method}

The method of the present study was quasiexperimental with a pre-test post-test design with a control group. The statistical population of the present study included all female high school students in Sarab city in the academic year 2019-2020. From this population, 45 female students were selected by convenience sampling and randomly divided into two experimental groups (30 people) and one control group (15 people). Pre-test was performed for all three groups and then training based on emotionalsocial skills in 12 sessions and problem-solving training in 10 sessions of 90 minutes as a group twice a week in the school was performed on two experimental groups. Inclusion criteria included being a single parent girl, age (15 to 18 years), exclusion criteria also included receiving another type of psychotherapy at the same time, absence of more than three sessions in treatment sessions and not continuing treatment.

After selecting the samples, the researcher provided the necessary and clear explanations about the objectives of the study, the method of conducting it, as well as maintaining the confidentiality of information, and received written informed consent from them. The therapist explained the social competency questionnaire to the subjects after establishing the initial therapeutic relationship. In this regard, the researcher had the role of guide, participant in the meeting or observer; All three groups were pre-tested and then emotional-social skills training based on 12 sessions and social problem-solving training in 10 sessions of 90 minutes as a group twice a week in the school was performed on two experimental groups and during During this time, members of the control group did not receive any intervention. Finally, after the treatment sessions, post-test was taken from all three groups. In this study, in order to collect data, a checklist containing demographic information (age, education, income level) and a social competency questionnaire were used. The data obtained from completing the questionnaires were analyzed using SPSS software version 24 and statistical indices and univariate analysis of covariance and Bonferroni post hoc test were used to test the research hypotheses. It should be noted that the level of significance in this study was considered 0.05 .

Table 1. Mean and standard deviation of subjects' scores in research variables

\begin{tabular}{cccccccc}
\hline Variable & Groups & \multicolumn{2}{c}{ Emotional-social } & \multicolumn{2}{c}{ Social problem solving } & \multicolumn{2}{c}{ Control } \\
\hline \multirow{2}{*}{ Social Competence } & & M & SD & M & SD & M & SD \\
& Pre-test & 138.86 & 4.45 & 138.46 & 3.70 & 137.06 & 5.38 \\
& Post-test & 145.14 & 2.16 & 144.40 & 2.87 & 142.06 & 2.25 \\
\hline
\end{tabular}

\section{Results}

The mean and standard deviation of students' age was $16.72 \pm 2.54 .62 \%$ of them lived with their father and $38 \%$ with their mother. In terms of parental education, 58\% had a diploma, 32\% a bachelor's degree, and $10 \%$ had a master's or doctorate degree. The average family income was reported to be close to 2 million. The mean and standard deviation of pretest-post-test scores of social competences in experimental and control groups are presented in Table 3. Also in this table, the results of Shapiro-Wilk test to report the normality of the distribution of variables in three groups are reported. According to this table, Shapiro-Wilk statistic is not significant for all variables. Therefore, it can be concluded that the distribution of variables is normal.

\section{Conclusion}

The aim of this study was to compare the effectiveness of emotional-social skills training and social problem-solving training on social competence of single-parent female high school students in Sarab. According to the research findings, emotional-social skills training was able to increase the social competence of single-parent girls.

Explaining the research findings, it can be said that adolescents who grow up in single-parent families face problems due to various problems in the family, such as being deprived of one parent's love, poverty and social interactions, and coping with peers. Training appropriate socio-emotional skills and providing opportunities and experiences that increase social interaction in these individuals and enable adolescents to develop social strategies and skills in 
all real-life environments and situations. Practice and apply (Gooding, 2011). Adolescents who learn the social rules of peer group well and also have strong relationships with family and community members are more likely to exhibit a high level of social adjustment; Adolescents who acquire good emotional and social skills and behave socially better have a more positive self-concept, and this leads to limitations and abilities. A more accurate way to evaluate, understand, and accept (McKown, Gumbiner, Russo \& Lipton, 2009).

On the other hand, the results of the present study showed that social problem-solving training led to an increase in social competence in single-parent female students. Explaining this finding, it can be acknowledged that problem-solving skills are acquired and part of it is obtained in the family by observing how parents respond to problems (Beirami et al., 1397). Although living in single-parent families can be effective in solving the social problems of children, but the problem-solving style of the present parent and his appropriate behaviors in dealing with conflicts and problems are more important. In the problem-solving teaching method, students work with a variety of hypotheses and tests, then they use the results they have obtained to help solve problems or present new ideas and new ideas. This method helps them to change their existing intellectual structure and draw new perspectives to solve problems and issues in various fields (Tlustos et al., 2016).

Overall, the results of the present study showed that based on the findings of the present study, socialemotional skills training and social problem-solving skills training had an effect on increasing the social competence of single-parent female students. These results indicate the importance of using psychological interventions in increasing social competence in single-parent female students; It can draw the attention of therapists and school counselors to the fact that in promoting the health of this group of people, the role of psychological factors should not be neglected and keep in mind that psychological interventions can achieve better results.

The present study has some limitations that have not been ineffective in obtaining the results. Lack of control of mediating variables affecting the social competence of students, limited age and gender of the sample also affected the results of this study. Due to time constraints, pre-test and post-test evaluation and measurement in the present study is short and had no follow-up stage. Therefore, it is suggested that future studies be performed with more time interval and follow-up stage.

\section{Ethical Considerations}

Compliance with ethical guidelines: This research is taken from the dissertation of the first author in the Islamic Azad University of Ardabil. It should be noted that in this study, the researcher, after obtaining approval from the ethics committee, IR.IAU.ARDABIL.REC.1399.047 performed the actual process.

Funding: This study was conducted without the financial support of any public or private institution or organization.

Authors' contribution: The first author is responsible for obtaining licenses, implementing protocols and questionnaires; The second author was responsible for writing the Persian and English abstracts, the introduction and the background of the research, and the third author was responsible for writing the conclusions, sources and formatting.

Conflict of interest: This research has not had any conflict of interest for the authors.

Acknowledgments: The authors would like to thank all the people who participated in this study. 


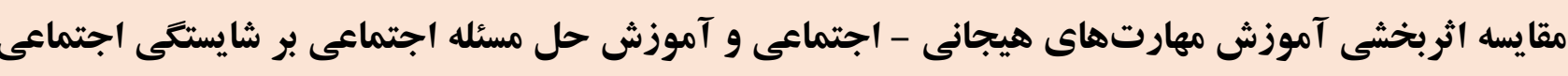 دانش آموزان دختر تك والد دوره دوم متوسطه}

\section{فاطمه مكرم'، رضا كاظمى *'، سميه تكلوى}

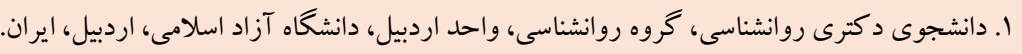

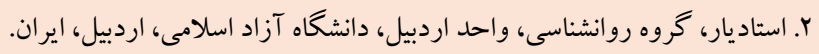

\section{جكيده}

زمينه: شايستخى اجتماعى به توانايى فرد در انجام امور مرتبط با استقلال شخصى خود و مسئوليتهاى اجتماعى اشاره دارد و موجب

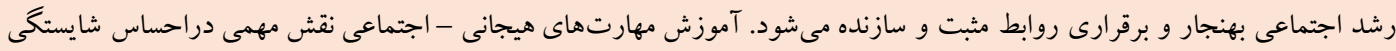

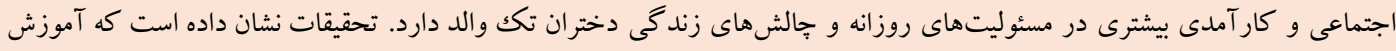

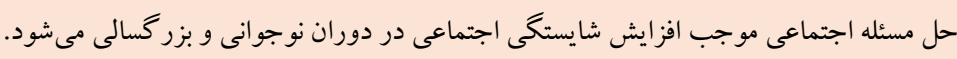

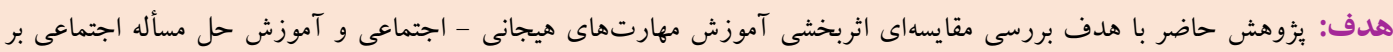

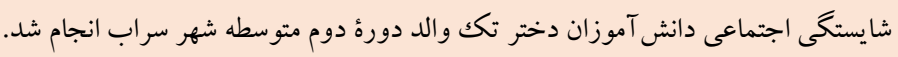

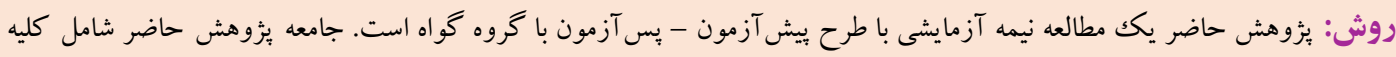

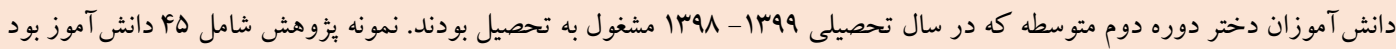

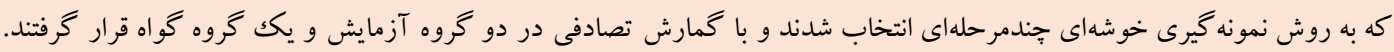

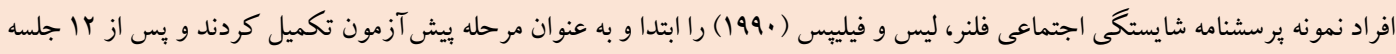

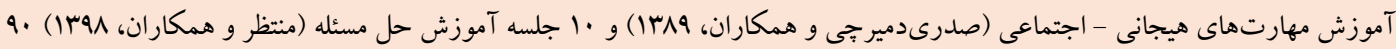

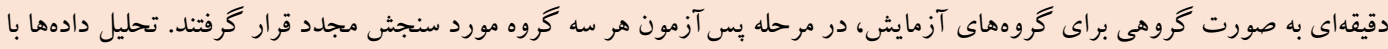

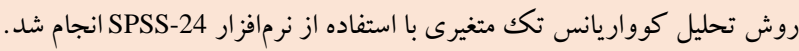

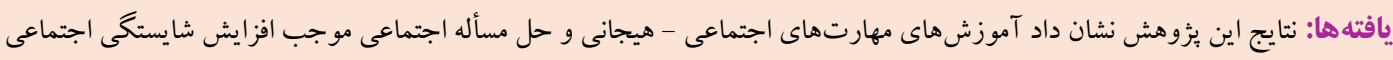

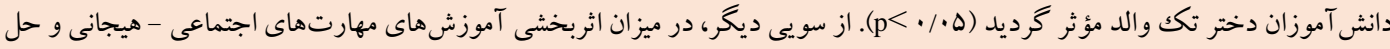

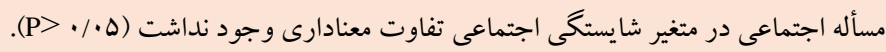

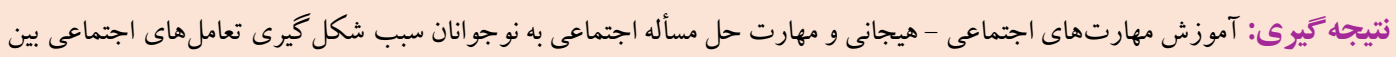

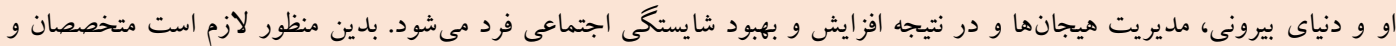

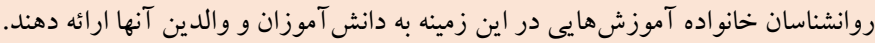

مشخصات مقاله

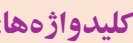
مهارتهاى هيجانى - اجتماعى، - ماكي، حل مسأله اجتماعى،

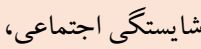

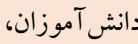

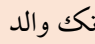

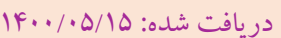
|f. |

* نويسنده مسئول: رضا كاظمى، استاديار، گروه روانشناسى، واحد اردبيل، دانشكاه آزاد اسلامى، اردبيل، ايران. راياناه: dr_reza.kazemi@yahoo.com 
مىشوند و براى كذر از آنها به ياد كيرى مهارتهاى مختلف از جمله

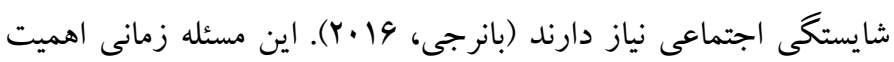

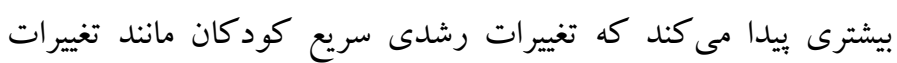

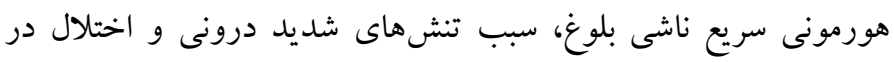

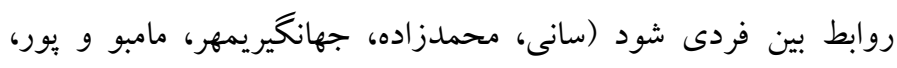
Y.IV استقلال شخصى و مسئوليت يذيرى اجتماعى تعريف مى گردد (هوسو كاوا

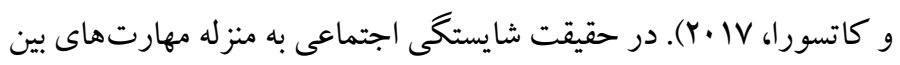

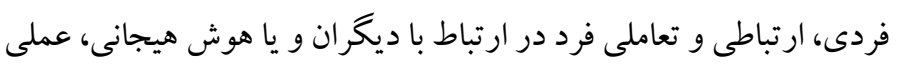

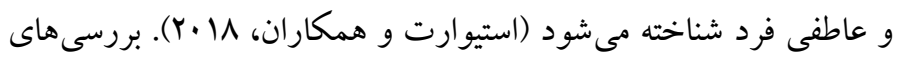

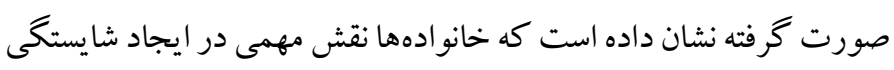

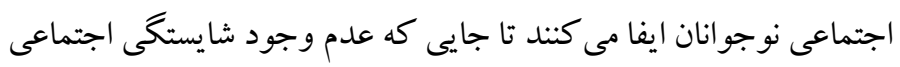

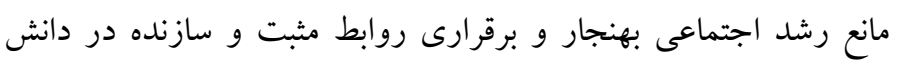

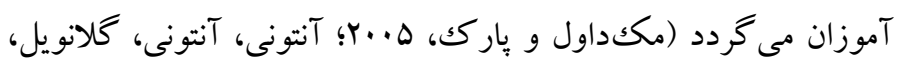

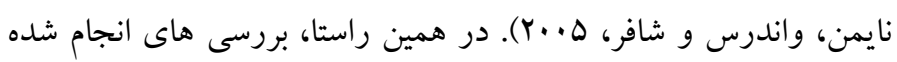

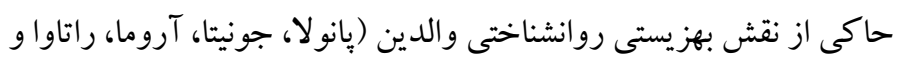

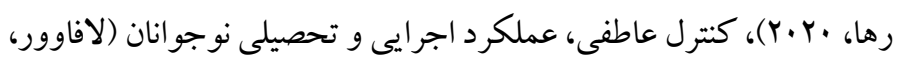

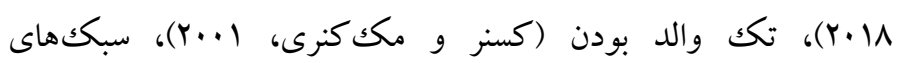

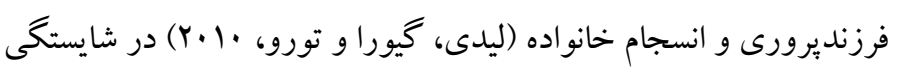
اجتماعى نوجوانان داشت. در واقع مى توان اذعان داشت خانو اده مهمترين نقش را در افزايش يا كاهش شايستخى اجتماعى فرزندان ايفا مى كند و واندان

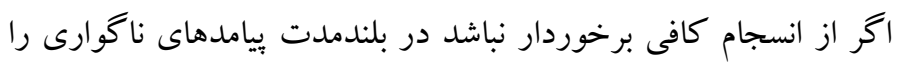

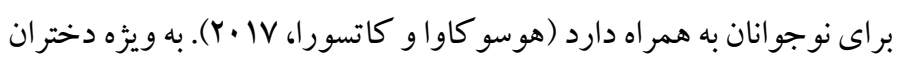
كه از حسايت عاطفى و هيجانى بيشترى برخوردارند و نيازمند دريافت

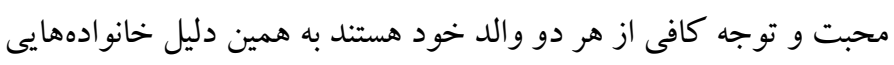

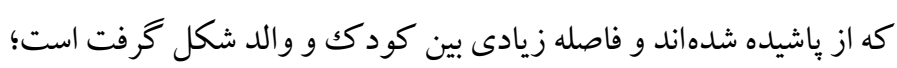

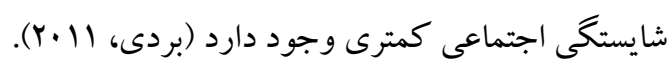
يكى از روشهايى كه مىتواند به افراد كمكك مى كند كه احساس إستى

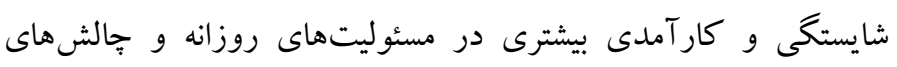

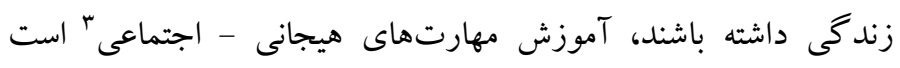

${ }^{3}$. Training Social-Emotional Skills dolo

تحولات اجتماعى طى دهه هاى گذشته منجر به تغيير بافت خانوادهها و

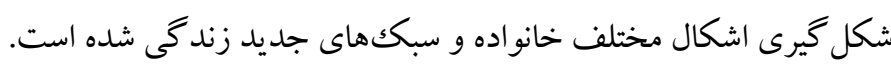

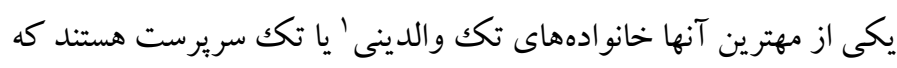

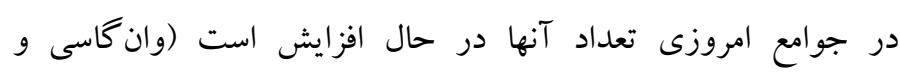

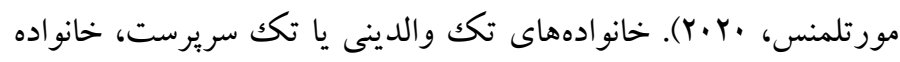

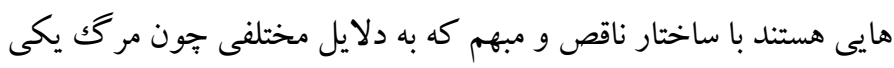

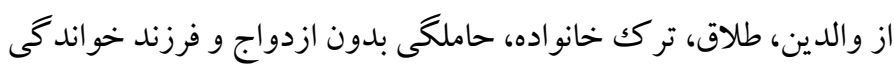

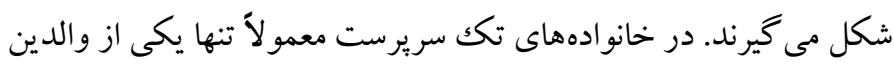

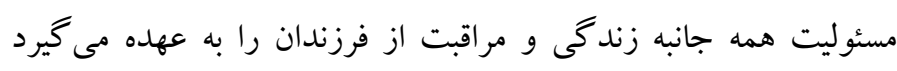

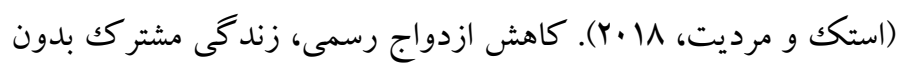

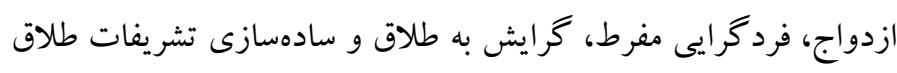

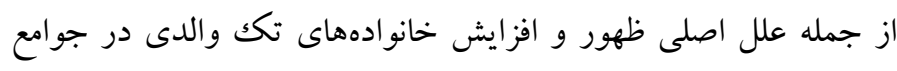

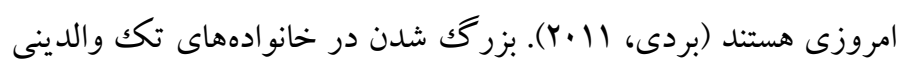

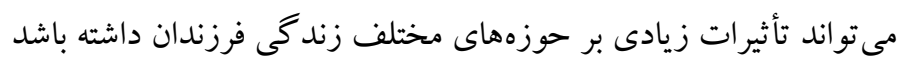

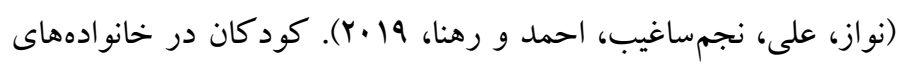
تكك والدينى نسبت به كودكان ساير خانوادهها بيشتر مستعد مشكلات روانشناختى و عاطفى هستند (فرانسون، لافتمن، اوستبر گك و بر گستروم،

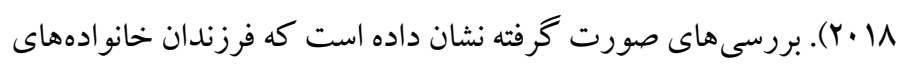

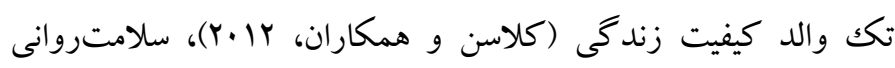

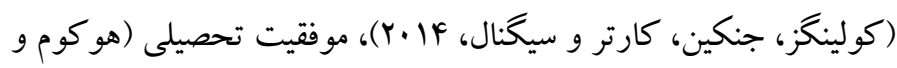

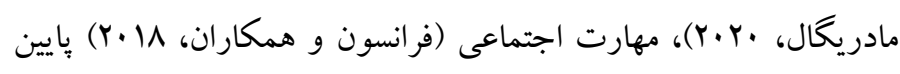

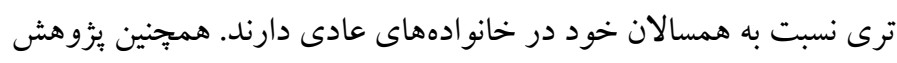

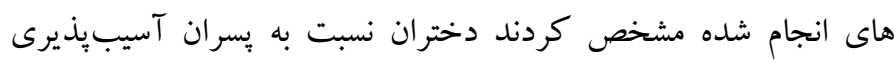

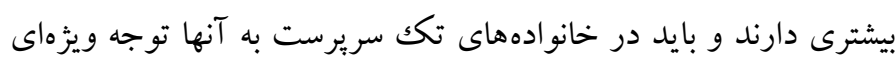

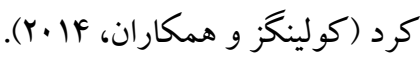
يكى از متغيرهايى كه مى تو اند تحت تأثير خانو ادههاى تكك والد قرار بـيرده،

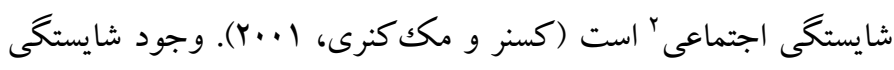
اجتماعى در نوجوانان مشغول به تحصيل امرى ضرورى است (ازوكا -

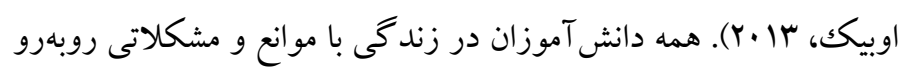

1. Single parent families

${ }^{2}$. Social competence 


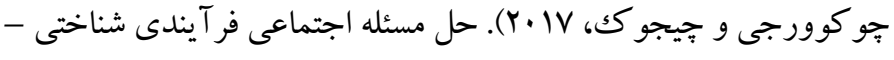
رفتارى و عاطفى است كه كليد مهمى در مديريت هيجانها، بهزيستى

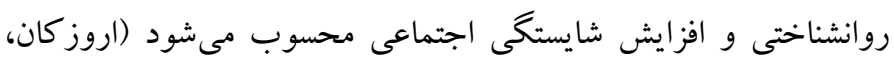

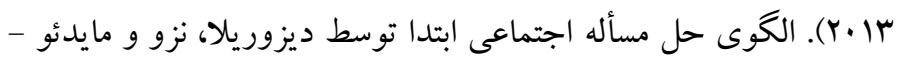

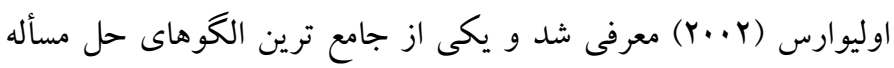

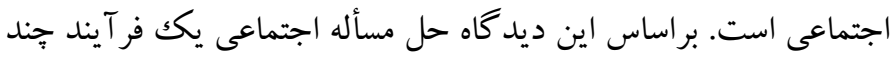
بعدى تعاملى است كه از دو مؤلفه نسبتاً مستقل جهت گيرى در مورئل مورد مسأله و سبكك هاى حل مسأله تشكيل شده است (مالوف، تورستينسون و اسشوت،

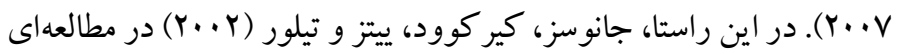
رابطه مهارت حل مسئله اجتماعى و شايستخى اجتماعى را در كودكان داراى آسيب مغزى مورد بررسى قرار دادند. در اين مطالعه كود كان داراى سهاى آسيب مغزى ضعيف، متوسط و شديد شركت داشتند. نتايج بدست آمده نشان داد كود كانى كه آسيب مغزى كمترى داشتند به صورت بهترى از

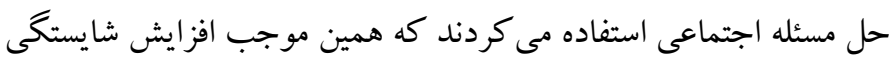

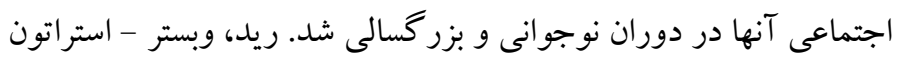

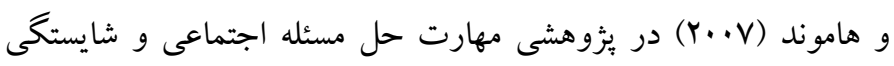
اجتماعى را در خانوداههاى داراى كودكان بر خطر مورد بررسى قرار دادند. نتايج اين مطالعه نشان داد والدينى كه تحت آموزش مهارتهاى دراى حل

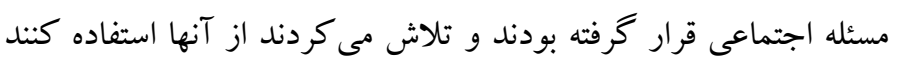
نسبت به ساير والدين شايستكى اجتماعى بيشترى را در كود كشان ايجاد

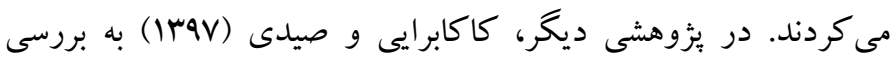

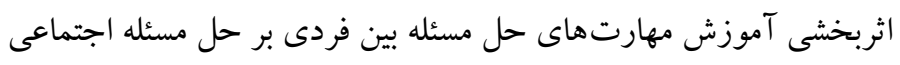

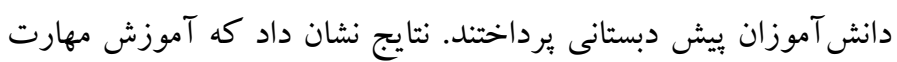

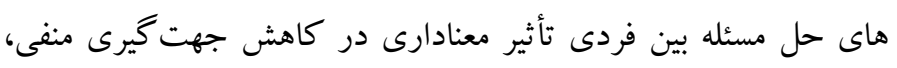

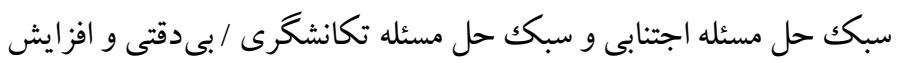
جهت گيرى مثبت و سبك حل مسئله منطقى دانش آموزان بيش دبستانى

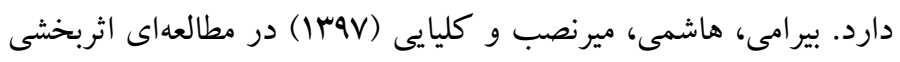
آموزش حل مسئله اجتماعى بر مؤلفهاى كفايت اجتماعى دانش آموزان ماني

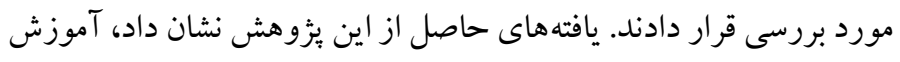
برنامه حل مسئله اجتماعى طر احى شده بر تمامى مؤلفههاى كفايت اجتماعى دانش آموزان، تأثير معنىدارى داشته است. تلوستوس، كير كوود، تيلور،
(كودين، 11.Y). منظور از مهارتهاى هيجانى - اجتماعى آن است كه نوجوان بر رفتارهايى كه سبب شكل گيرى تعاملهاى اجتماعى بين او و و

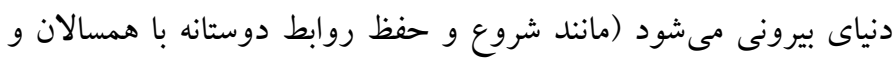

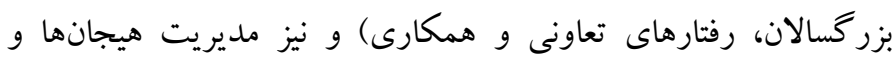

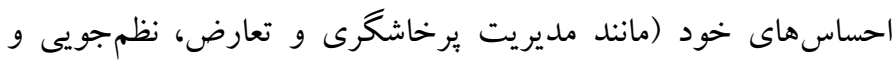
واكنش بذيرى) تسلط يابد و به تحول حس مهارت و ارزش خود دست

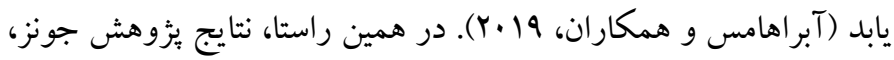

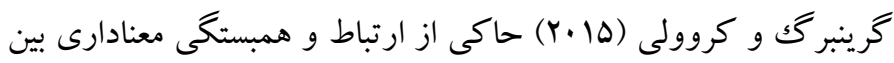

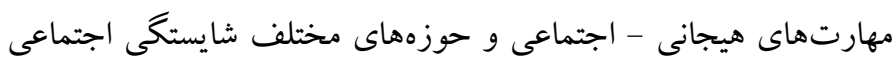
داشت. در واقع كودكانى كه در طول اين سالها از مهارت هيجانى اجتماعى مناسبى برخوردار بودند گرايش كمترى نسبت به فعاليتهاى

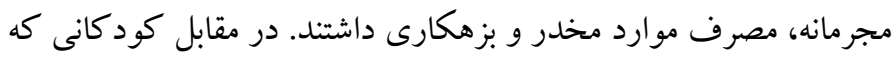
مهارت هيجانى - اجتماعى پايينى داشتند در تحصيل و اشتغال موفقيتى

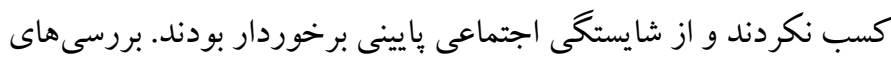

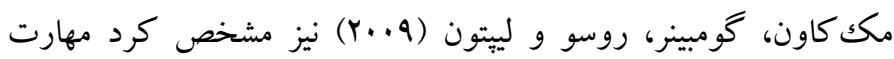

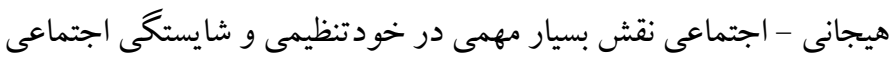

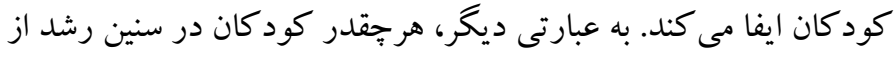
نظر مهارتهاى هيجانى - اجتماعى در سطح بالاترى قرار بخيرند در آينده خود تنظيمى و شايستكى اجتماعى بهترى خواهند داشت. در داخل كشور

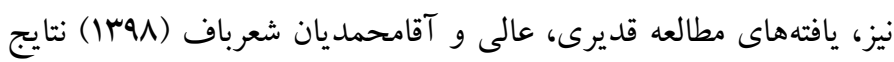

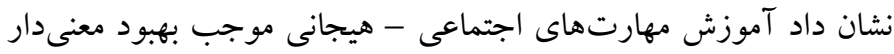
ميزان تابآورى دانش آموزان شركت كننده در كروه آزمايش نسبت به

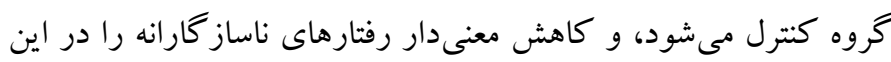

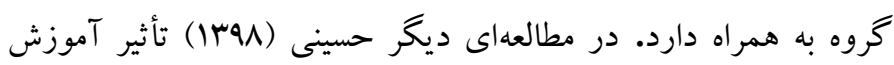

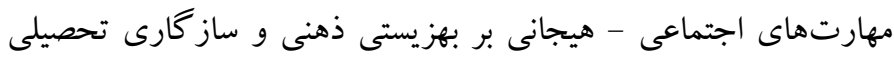
دانش آموزان مورد بررسى قرار داد. يافتههاى بدست آمده حهاكى آهى از تأثير

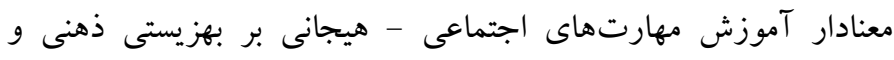
ساز گارى تحصيلى دانش آموزان داشت.

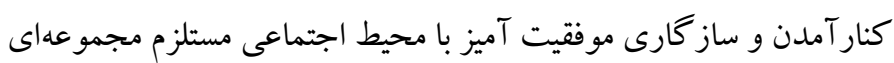
مهارتهاى حل مسئله نيز است كه نمى توان آنها را بوسيله آزمونهاى

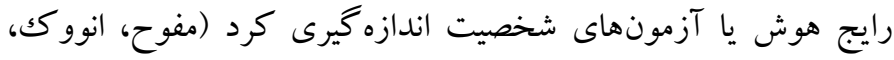

1. Problem solving skills 
جامعه آمارى يزوهش حاضر شامل كلية دانش آموزان دختر دورهُ دوم

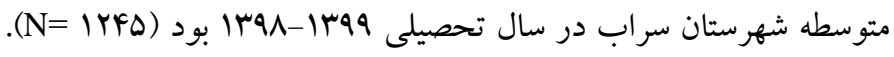
از اين جامعه، ها دانش آموز دختر به صورت در دسترس انتخاب و به

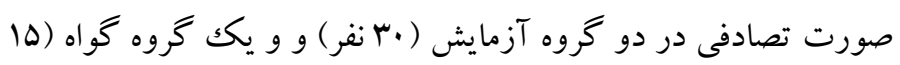
نفر) قرار گرفتند. از هر سه گروه ييش آزمون به عمل آمد و سبس آموزش مهارتهاى هيجانى - اجتماعى مبتنى طى Y| جلسه و آموزش حل مسئله طى ·ل جلسه •9 دقيقهاى به صورت گرووهى هفتهاى دوبار، درمدرسه بر روى دو كروه آزمايش اجرا كرديد. ملاككهاى ورود به يزوهش شامل دختر تكك والد بودن، سن (ها تا \1 سال)، معيارهاى خروج نيز شامل دريافت همزمان نوع ديخرى از رواندرمانى، غيبت بيش از سه جلسه در جلسات درمانى و عدم ادامه درمان بود.

ب) بابز إر برسشنامه شايستخى اجتماعى: اين يرسشنامه براساس نظريه فلنر، ليس و فيليس ( •199) براى بررسى نيمرخ ظرفيتهاى كودك و نوجوان توسط

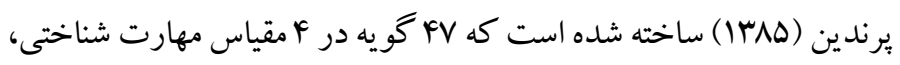
مهارت رفتارى، شايستكى هيجانى و آمايه انكيزشى دارد و مهارت فوق را Vى V V V درجهاى ياسخ مى دهند. بدين ترتيب كه آزمودنى كزينه كاملاً مخالفم را انتخاب كند نمره (ا، مخالفم نمره Y، تا حدى مخالفم نمره س، نظرى ندارم

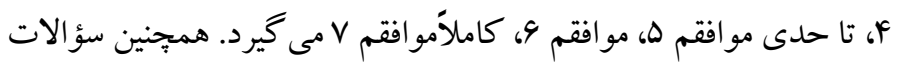

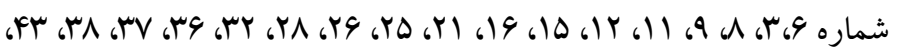

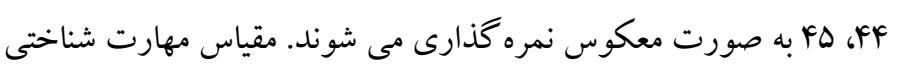

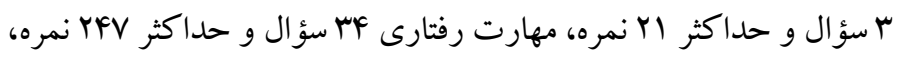
شايستكى هيجانى ب سؤال و حداكثر اY نمره و آمايه انكيزشى V سؤال و حداكثر qq نمره دارد. شاخص روانسجى اين ثيرسشنامه توسط برندين، بررسى شده كه ضريب يايايى آن با روش آلفاى كرونباخ MM/ •، و روايى به روش تحليل عاملى تأييد شده كه مقدار شايستكى نمونه بردارى آن Ar/ •

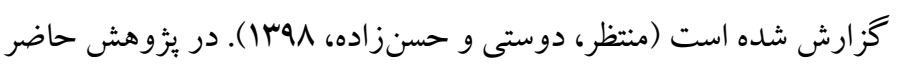
نيز ضريب آلفاى كرونباخ اين مقياس \&A/ • بدست آمد. بِ از دريافت كد اخلاق از كميته اخلاق دانشكاه آزاد اسلامى واحد اردبيل (IR.IAU.ARDABIL.REC.1399.047)، براى جمع آورى دادهها
استانجين، بروون و وادى (19 ·r) در يُروهشى ديخر به بررسى آموزش حل

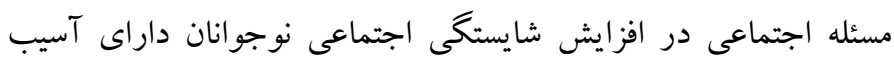

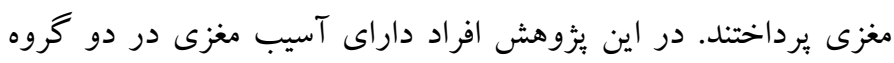

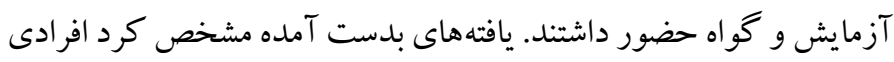

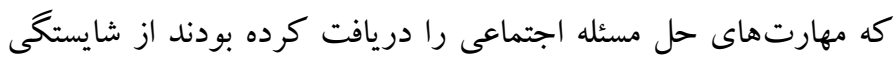
اجتماعى مناسب ترى برخوردار بودند. البته به شدت آسيب و سن افراد نيز آنيز

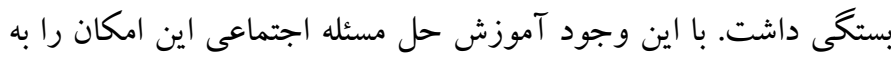

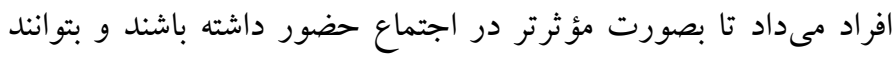
فعاليت هاى خود را تا حدى انجام دهند. در مجموع مى توان گفت والدين در خانوادهاى تكك والدى اغلب به دليل تعدد نقش دجار فشار روانى مىشوند، به خصوص زمانى كه آنها دو يا كنائ

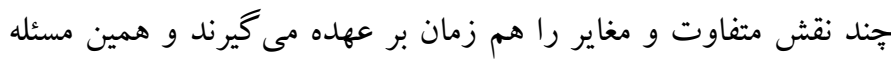

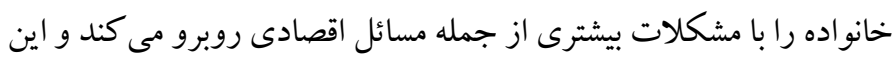

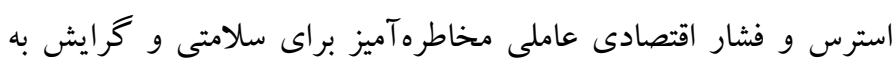
مشكلات رفتارى در فرزندان اين خانوادهها به حساب مئ آيد (استكك و

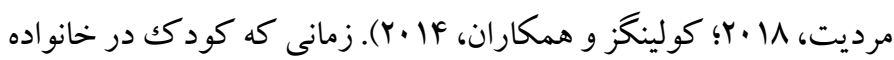

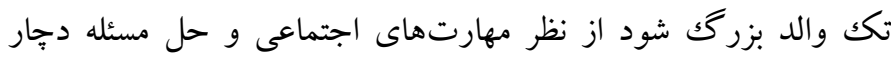
ضعفهايى است كه بر روى عملكرد تحصيلى، اعتماد به نفس، ارتباطات

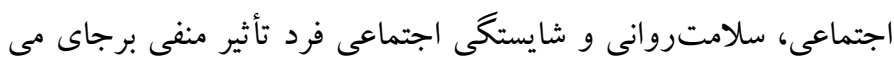

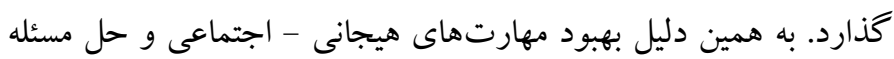

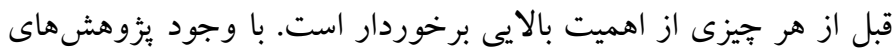
فراوان در مورد آسيبهاى خانواده تكك والدى، هنوز جنبهائهاى نا شناختها بسيارى در اين خانوادهها و فرزندان آنها وجود دارد كه نيازمند بررسى

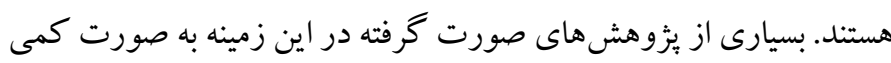

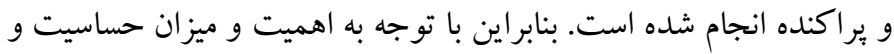

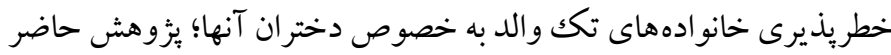

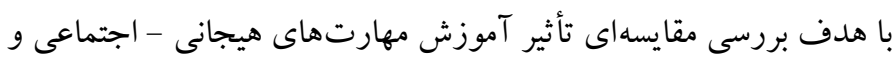

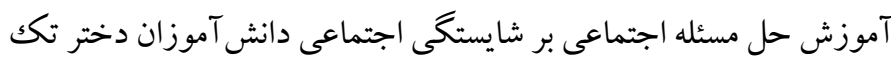

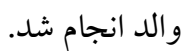
روش

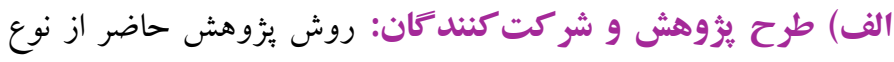

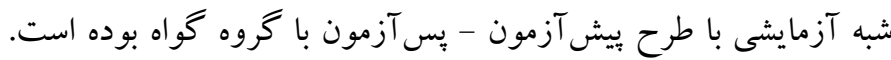


آموزش حل مسئله اجتماعى طى ·. جلسه ·9 دقيقهاى به صورت گروهى هفتهاى دوبار، درمدرسه بر روى دو گروه آزمايش اجرا گرديد و در طى اين مدت اعضاى كروه كنترل هيج مداخلهاى دريافت نكرد. در نهايت بس از يايان جلسات درمانى از هر سه گروه يس آزمون گر فته شد. در اين

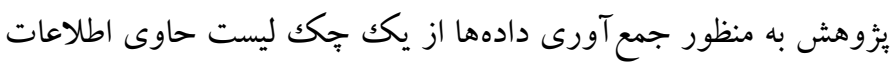
جمعيتشناختى (سن، تحصيلات، ميزان در آمد) و يرسشنامه شايستكى اجتماعى استفاده شد. دادههاى حاصل از تكميل پرسشنامهها با استفاده از نرمافزار آمارى SPSS نسخه YF تحليل شده و از شاخصهاى آمارى و تحليل كوواريانس تكك متغيره و آزمون تعقيبى بونفرونى به منظور آزمون فرضيه هاى يزوهش استفاده شد. لازم به ذكر است سطح معنىدارى در اين يزؤهش ه • • • در نظر كرفته شد.
ابتدا يزوهشخ مجوزهاى لازم را از آموزش و يرورش شهرستان سراب دريافت كرد. سيس از ميان دانش آموزان دختز شهرستان سراب تعداد ها نفر از دانش آموزان دختر تكك والد دوره دوم متوسطه به روش نمونه گيرى خوشهاى جندمر حلهاى وارد مطالعه شدند و به وسيله گمارش تصادفى در دو گروه آزمايش ( •س نفر) و يكك گروه گواه (ها نفر ) قرار گرفتند. بعد از انتخاب نمونه ها يزوهشكر توضيحات لازم و روشن در خصوص اهداف مطالعه، روش انجام آن و نيز حفظ محرمانه ماندن اطلاعات را ارائه نموده و رضايتنامه آكاهانه كتبى از آنها دريافت نمود. بدين صورت كه درمانگر بعد از برقرارى رابطه درمانى اوليه، يرسشنامهها را براى آزمودنى لهیى ها توضيح داد. در اين راستا يثروهشخر نقش هدايت كننده، شركت كنتده در جلسه و يا مشاهده گر را داشت؛ از هر سه گروه ييش آزمون به عمل آمد و سبس آموزش مهارتهاى هيجانى - اجتماعى مبتنى طى با جلسه و

جدول ا. خلاصه جلسات مهارت هاى هيجانى - اجتماعى (بر كرفته از صدرىدمير جى و همكاران،

\begin{tabular}{|c|c|c|}
\hline خلاصه جلسات & اهداف & \\
\hline بحث و بررسى اهميت آموزش مهارتهاى هيجانى - اجتماعى، معرفى و آشنايى اعضا با يكديخر و رهبر گروه، مطرح كردن قوانين و & آشنايى & اول اول \\
\hline مشاهده و شناخت احساسات خود؛ شناخت نقاط ضعف و قوت خود، يافتن واز كانى براى بيان احساسات، آكاه شدن از ارتباط ميان & خود آكاهى & 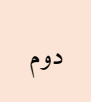 \\
\hline 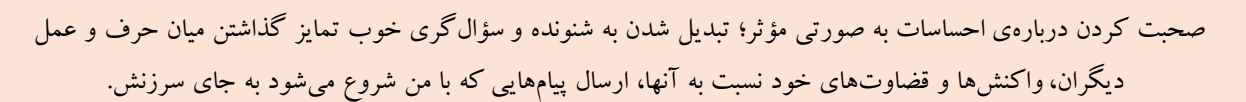 & روابط بين فردى & 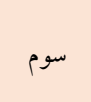 \\
\hline آشنايى با مراحل تصميم گيرى، بررسى اعمال خود و ديخران و آكاهى بر ويامدهاى آنها، تشخيص آنكه بر تصميمى خاص، انديشه يا & تصميم گيرى شخصى & 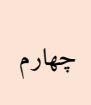 \\
\hline 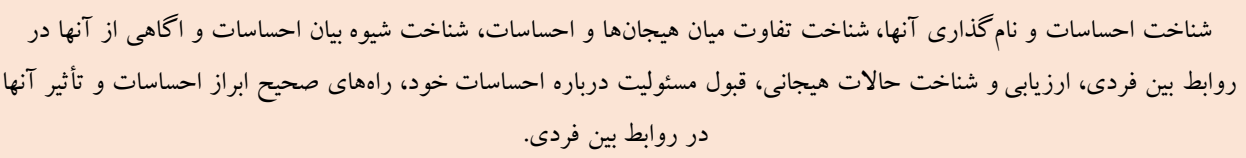 & شناخت احساسات & ينجم \\
\hline دركى احساسات و علايق ديخران و مدنظر قرار دادن دورنماى ذهنى آنان، احترام گذاشتن به تفاوتهاى موجود در احساسات افراد، & همدلى & 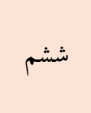 \\
\hline 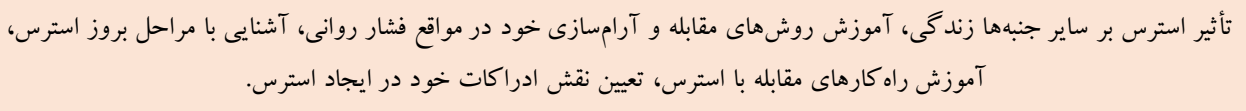 & مقابله با استرس & 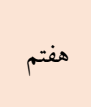 \\
\hline لزوم انعطافيذيرى در رسيدن به هدفهاى خود و ساز گارى با محيط و تغييرات، نحوه ساز كارى و انعطافيذيرى در مقابل تغييرات. & انعطافيذيرى در مقابل تغيير & 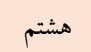 \\
\hline مراحل حل مسئله، برنامهريزى در حل مسائل زندگى، موانع حل مسئله، آكاهى از نحوه دريافت كمك در حل مسائل اساسى زندگى. & حل مسئله & نهم \\
\hline نقش كنترل هيجانها در عملكرد افراد، كنترل هيجانها به شيوه مؤثر، علايم و نشانهاى ابراز خشم، روشهاى ابراز خشم در افراد، & كنترل هيجانها & دهم \\
\hline تفاوت ابراز وجود و رفتار برخاشخرانه، شناسايى رفتارهاى نشان دهندهى ابراز وجود، مهارتهاى افزايش توانايى ابراز وجود، آموزش & ابراز وجود & يازدهم \\
\hline 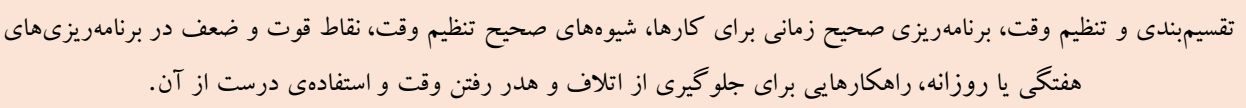 & مديريت زمان & دوازدهم \\
\hline
\end{tabular}




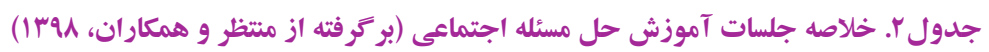

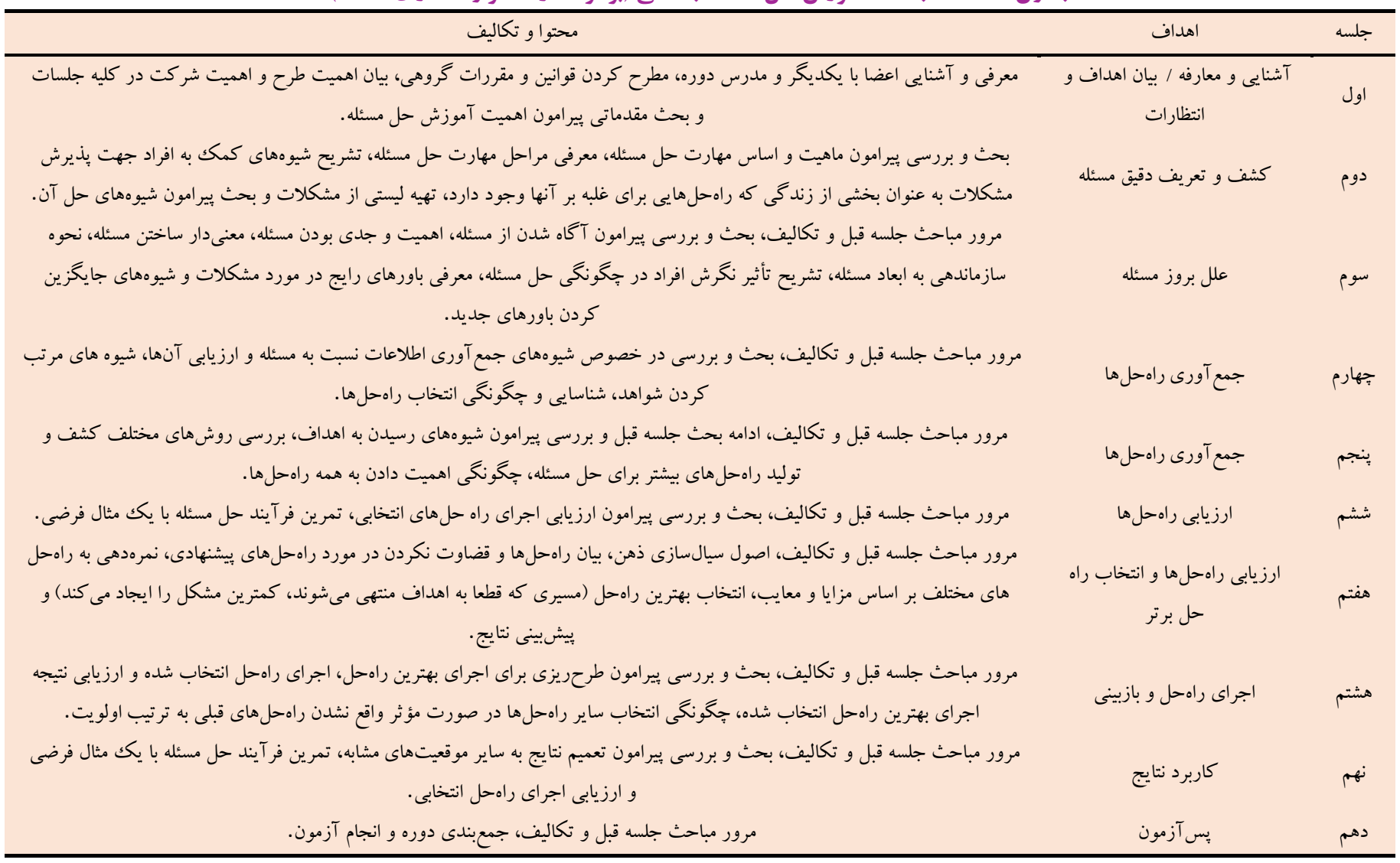

ميليون گزارش گرديد. ميانگين و انحراف استاندارد نمرات بيش آزمون -

يافتها ها

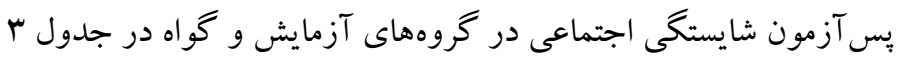

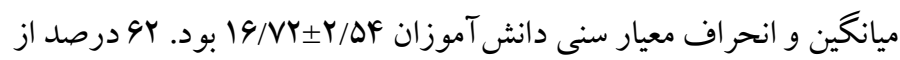
ارائه شده است. همجينين در اين جدول نتايج آزمون شاييرو - ويلك بر بر ایى آنها با بدر ^ب درصد با مادر زندگى مى كردند. از نظر تحصيلات والدين بررسى نرمال بودن توزيع متغيرها در سه گروه گزارش شده است. با توجه

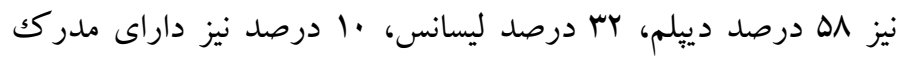

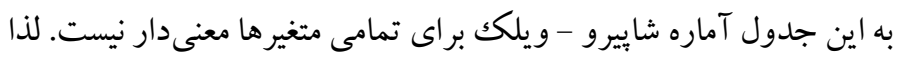
مى توان نتيجه گرفت كه توزيع متغير ها نرمال است.

جدول س. ميانتين و انحر اف استاندارد شايستىى اجتماعى در بيش آزمون - يس آزمون دو كروه آزمايش و يك تروه تواه

\begin{tabular}{|c|c|c|c|c|c|c|}
\hline $\mathrm{P}$ & شايِيرو - ويلك & \multicolumn{2}{|c|}{ يس آزمون } & \multicolumn{2}{|c|}{ يُش آزمون } & عضويت گروهى \\
\hline$\cdot / \cdot A V$ & - /IFA & $r / 19$ & IFD/IF & $F / \& \Delta$ & IrN/A9 & هيجانى - اجتماعى \\
\hline.$/ .99$ & - /TFA & Y/AV & $\mid F F / F$. & $r / v$ & IrN/FG & حل مسئله اجتماعى \\
\hline$\cdot / \cdot v r$ & .11 .9 & Y/TS & $\mid \mathrm{Fr} / .9$ & $\Delta / A r$ & $1 \mathrm{rV} / .9$ & گروه گواه \\
\hline
\end{tabular}

راهه استفاده شد. نتايج آزمون بررسى شيب رگرسيون بيش آزمون و يس آزمون شايستخى اجتماعى در گروههاى آزمايش و گواه، نشان داد كه

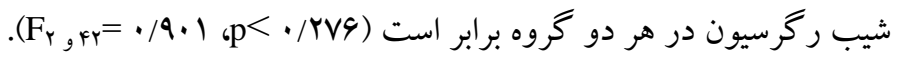

براى بررسى بررسى مقايسهاى اثربخشى آموزش مهارتهاى هيجانى اجتماعى و آموزش حل مسأله اجتماعى بر شايستكى اجتماعى دانش آموزان دختر تكك والد دورهُ دوم متوسطه از تحليل كوواريانس يكك 
ميز ان شايستكى اجتماعى تفاوت معنى دارى وجود دارد. اندازه اثر اب// نيز نشان مى دهد كه اين تفاوت در جامعه بزرگ است. آماره F ييش آزمون

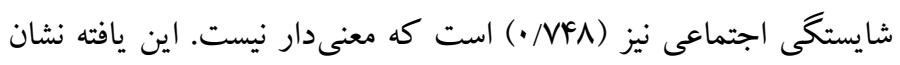
مىدهد كه ييش آزمون تأثير معنى دارى بر نمرات يس آزمون ندارد. با توجه به بالا بودن ميانگين نمرات يس آزمون در گروههاى آزمايش، ميزان شايستكى اجتماعى دانش آموزان دختر تكك والد نسبت به كروه كواه افزايش يافته است. - است
نتايج آزمون لوين براى بررسى همخنى واريانس متغير وابسته در كروهها نشان داد كه واريانس شايستكى اجتماعى در گروهها برابر است

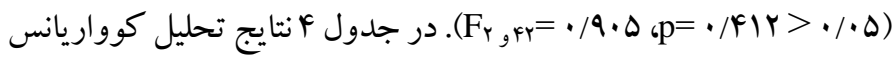
تكك متغيرى بر اي بررسى تفاوت كروههاى آزمايش و كو اه در بيش آزمون و يس آزمون متغير شايستخى اجتماعى گز ارش شده است. با توجه به جدول F F Fآماره شايستى اجتماعى در يس آزمون (ه/99) است كه در سطح ه• • معنى دار است كه اين نشان مىدهد كه بين سه كروه در

\begin{tabular}{|c|c|c|c|c|c|c|}
\hline اندازه اثر & سطحمعنىدارى & F Tاره F & ميانگين مجذورات & درجهآزادى & مجموع مجذورات & منبع \\
\hline$\cdot / \mathrm{VA}$ & $\cdot \cdots 1$ & $\mid F V / a T$ & $\wedge ৭ \% / \wedge q$ & 1 & $\wedge ৭ r / \wedge q$ & الخوى اصلاحشده \\
\hline$\cdot / \cdot r$ & •/rar & $\cdot / V F \Lambda$ & $F / \Delta 1$ & 1 & $F / \Delta 1$ & يِيش آزمون \\
\hline$\cdot / r 1$ & $\cdot / \cdot v$ & $\Delta / 99$ & $9 N /{ }^{\prime} \Lambda$ & r & $9 \Lambda / \Gamma \Lambda$ & عضويت گروهى \\
\hline- & - & - & $91 \cdot 4$ & Fi & $Y F V / V F$ & خطا \\
\hline
\end{tabular}

جدوله. آزمون تعقيبى بنفرونى براى مقايسه زوجى تروههاى آزمايشى در ميزان اثربخشى برنامههاى آموزشى

\begin{tabular}{|c|c|c|c|c|}
\hline معنىدارى & انحر اف استاندارد & تفاوت ميانكين & Loog & متغير وابسته \\
\hline $1 / \cdots$ &.$/ 194$ & $\cdot / N \cdot 4$ & مهارتهاى اجتماعى - هيجانى & شايستكى اجتماعى \\
\hline
\end{tabular}

همسالان با مشكلاتى روبرو هستند. آموزش مهارتهاى هيجانى اجتماعى مناسب و فراهم كردن فرصتها و تجربههايى كه تعاملات اجتماعى را در اين افراد افزايش مىدهد وموجب مىشود نوجوانان بتوانند راهبردها و مهارتهاى اجتماعى را در تمام محيطها و موقعيتهاى واقعى

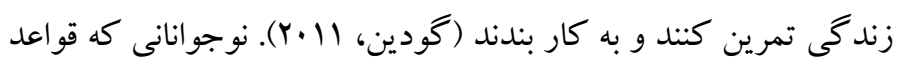
اجتماعى گروه همسالان را به خوبى ياد مى گيرند و نيز روابط قوى و مستحكمى با اعضاى خانو اده و اجتماع برقرار مى كنند، به احتمال زياد،

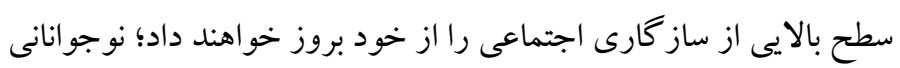
كه به خوبى مهارتهاى هيجانى اجتماعى را به دست مى آورند و از نظر اجتماعى رفتارهاى مطلوبترى از خود نشان مىدهند، مفهوم خود مثبت ترى دارند و اين امر موجب مى شود محدوديتها و توانايىهاى خود رابه شيوه صحيحترى ارزيابى، دركك و يذيرش كنند (مكك كاون و همكاران،

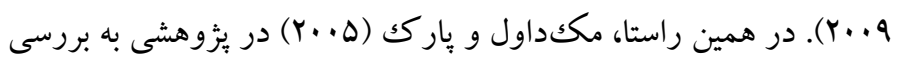
كنترل والدين در بيشبينى شايستكى اجتماعى كود كان برداختند. در اين يثوهش V9 كودكك و والد شركت داشتند. نتايج اين مطالعه نشان داد والدينى كه بر روى رفتارهاى كودكشان كنترل كافى دارند و نسبت به
نتايج حاصل از جدول ه نشان مىدهد كه در ميزان اثربخشى آموزش مهارت هاى اجتماعى - هيجانى و آموزش مهارت حل مسأله اجتماعى در متغير شايستكى اجتماعى تفاوت معنى دارى وجود ندارد.

\section{بحث و نتيجه تيرى}

يزوهش حاضر با هدف بررسى مقايسهاى اثربخشى آموزش مهارتهاى هيجانى - اجتماعى و آموزش حل مسئله اجتماعى بر شايستكى اجتماعى دانش آموزان دختر تكك والد دورة دوم متوسطه شهر سراب انجام شد. بر طبق يافتهاى يزوهش، آموزش مهارت هيجانى - اجتماعى توانست

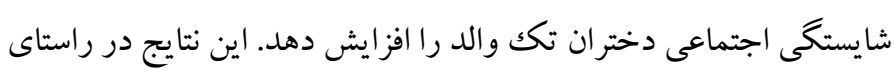

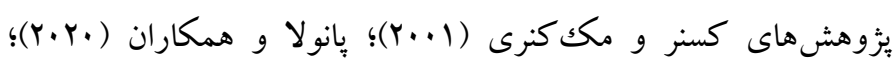

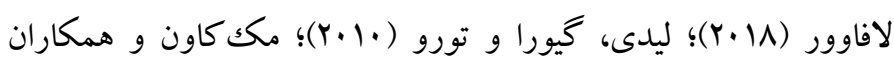

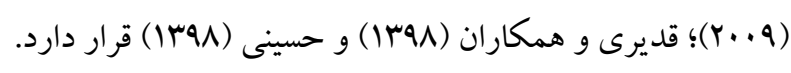

در تبيين يافتهاى يثزوهش مى توان كفت نوجوانانى كه در خانو ادههاى تكك والدى بزرگك مى شوند به علت مشكلات مختلف در خانو اده مانند محروم بودن از محبت يكى از والدين، فقر و تعاملات اجتماعى و سازش با 
كه با تلاش، مسائل قابل حل هستند و با استفاده از مهارت مسئله گشايى، به خوبى مىتواند احساس شايستكى و تسلط را در خود ايجاد كنند.

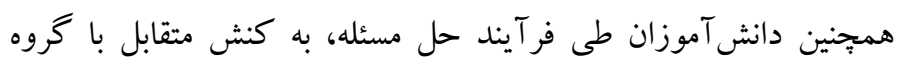

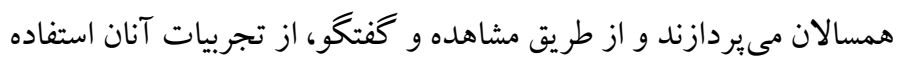

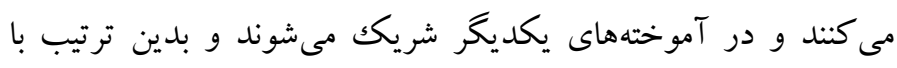

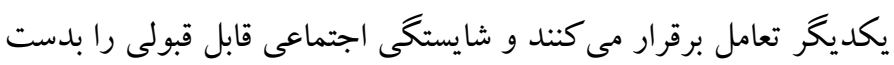

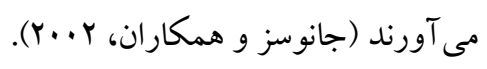

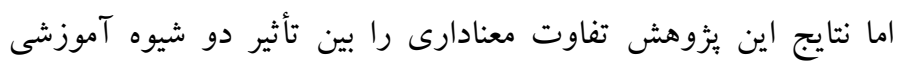

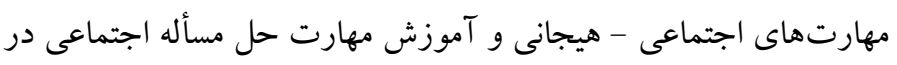
افزايش شايستخى اجتماعى دانشآموزان دختر تكك والد نشان نهان نداد؛

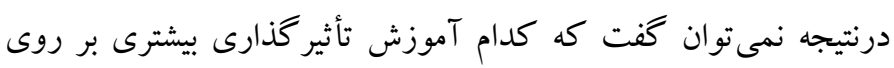

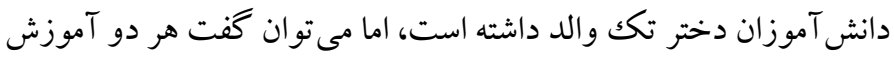
بر شايستكى اجتماعى مؤثر بوده است و اين توانايى را دارند تا كمى از

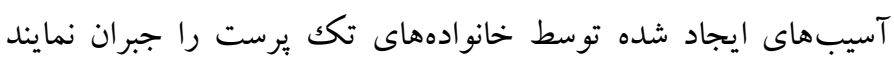

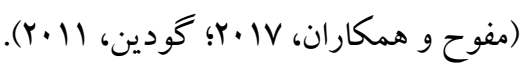

در مجموع نتايج يزوهش حاضر نشان داد كه براساس يافتهاى مطالعئ

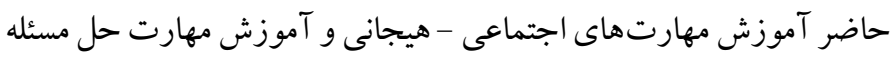
اجتماعى بر افزايش شايستخى اجتماعى دانش آموزان دختر تك إنى والد تأثير

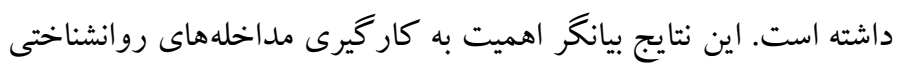

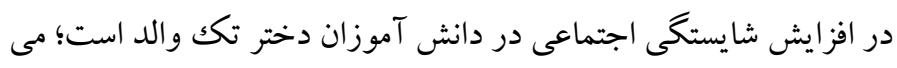

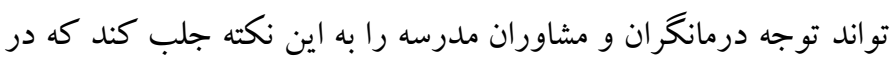
ارتقاى سلامت اين دسته از افراد، نبايد از نقش عوامل روانشناختى غافل شد و در نظر داشته باشند كه با مداخلات روانشناختى مىتوان به نتايج

$$
\text { مطلوبترى دست يافت. }
$$

يُوهش حاضر محدوديت هايى را داشته است كه در به دست آوردن نتايج آن بى تأثير نبوده است. عدم كنترل متغيرهاى واسطهاى مؤثر بر شايستخى

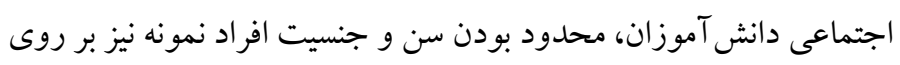

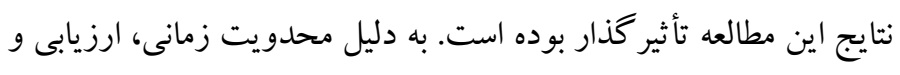
سنجش بيش آزمون و بِ آزمون، در مطالعه حاضر كو تاه مىباشد و مرحله

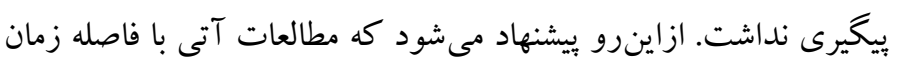

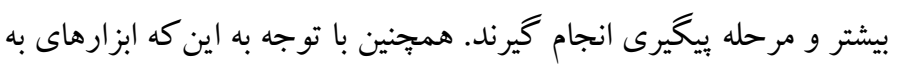

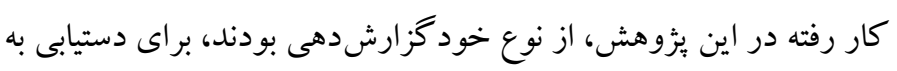

ياسخهاى آنها واكنش مثبت و منفى نشان مىدهند؛ شايستخى اجتماعى

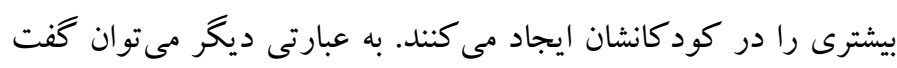

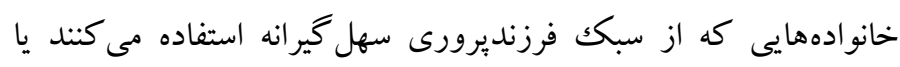
خانوادههاى تكك والد كه نظارتى بر رفتارهاى كود كشان ندارند منجر به شكل گيرى و تربيت كود كى با شايستخى و خود كار آمدى اجتماعى بايين

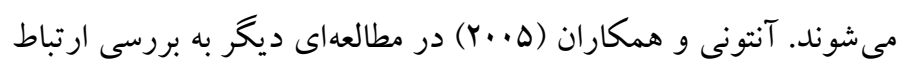

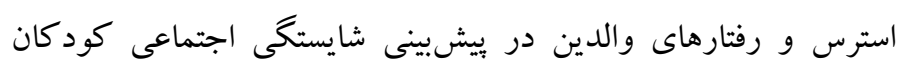

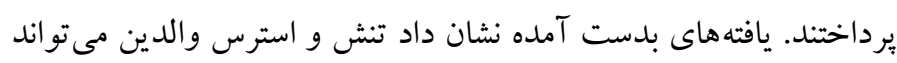

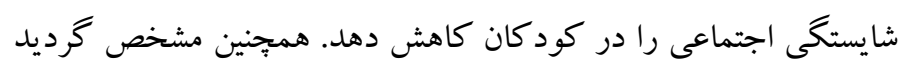

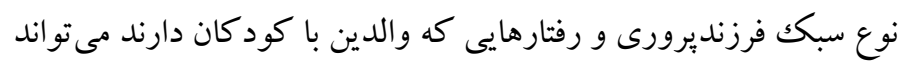
شايستخى اجتماعى آنها را تحت تأثير قرار دهد.

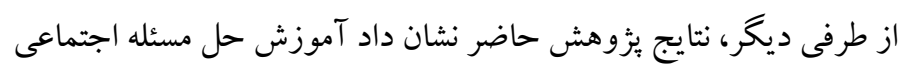
منجر به افزايش شايستكى اجتماعى در دانش آموزان دختر تكك والد شد.

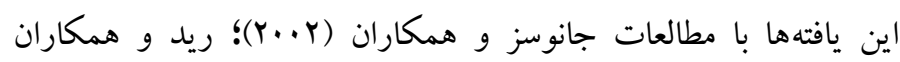
(Y..V) تلوستوس و همكاران (Y. 19) همسو است.

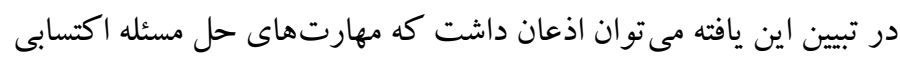

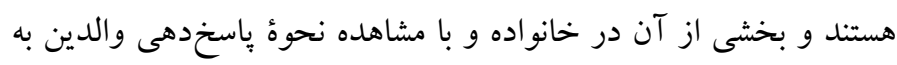

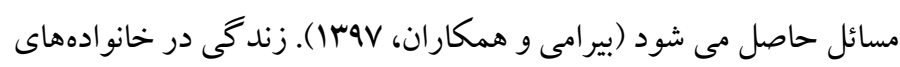

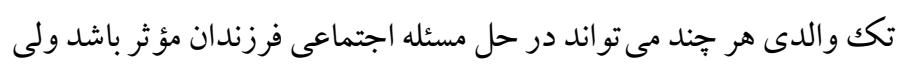

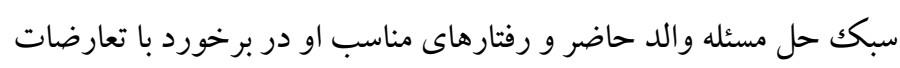

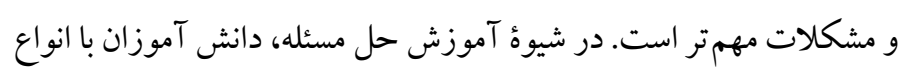
فرضيهها و آزمونها كار مى كنند، سبس آنان از نتايجى كه به دست آنس آورده

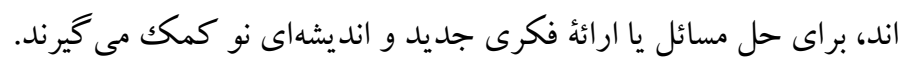
اين شيوه به آنان براى تغيير ساختار فكرى موجود خويش و و ترسيم جشئ

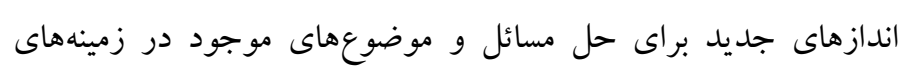

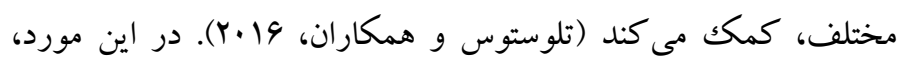

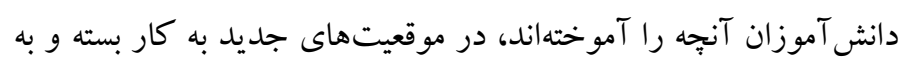
نو آفرينى دست مىزنند و از اين طريق، خود كار آمدى خود را نيز نشان اندان

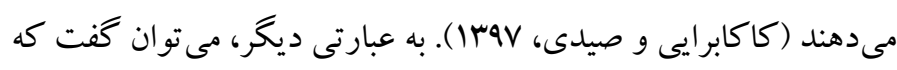

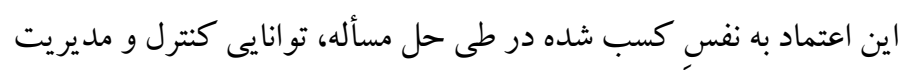

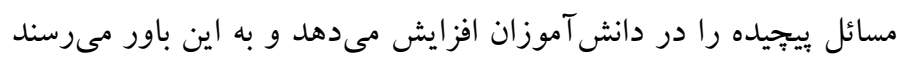


حامى مالى: اين مطالعه بلدون حمايت مالى هيج مؤ سسه و سازمان دولتى يا خصو صى انجام شده است. نقش هر يكك از نويسند كان: نويسنده نخست، در طراحى، مفهوم سازى، گردآورى و تحليل آمارى دادهها، نويسـنده دوم در روش شــناسى، مفهومســازى و نهايىسـازى و

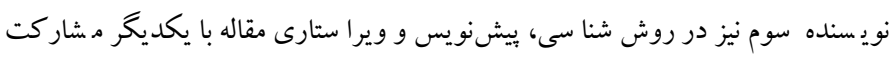
داشتند. تضاد منافع: اين يزٔوهش براى نويسند كان هيج گونه تضاد منافع نداشته است. تشكر و قدردانى: بدينوسيله نويسند گان از مديران و مشاورين مدارس دخترانه دولتى، نمونه دولتى، تيزهوشان و غير انتفاعى شهرستان سراب كه در انجام هر جه بهتر اين تحقيق

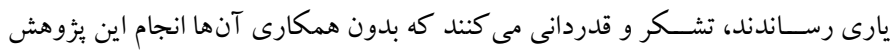

$$
\text { ميسر نبود. }
$$

نتايج دقيقتر بيشنهاد مىشود از مشاهده و مصاحبه بالينى نيز استفاده شود. در عين حال بر اساس نتايج يزوهش حاضر مى توان بيشنهاد داد برنامهها و كار كاههايى در زمينه بالا بردن مهارتهاى هيجانى - اجتماعى و حل مسئله اجتماعى والد و كودك تشكيل كردد.

\section{ملاحضات اخلاقى} بيروى از اصول اخلاق يخوهش: اين يزٔوهش بر گرفته از باياننامه دكترى تخصصى

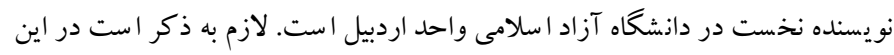

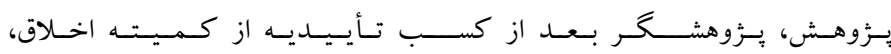

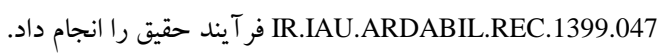




\section{References}

Azuka-Obieke, U. (2013). Single-parenting, psychological well-being and academic performance of adolescents in Lagos, Nigeria. Journal of Emerging Trends in Educational Research and Policy Studies, 4(1), 112-117. [Link]

Anthony, L. G., Anthony, B. J., Glanville, D. N., Naiman, D. Q., Waanders, C., \& Shaffer, S. (2005). The relationships between parenting stress, parenting behaviour and preschoolers' social competence and behaviour problems in the classroom. Infant and Child Development: An International Journal of Research and Practice, 14(2), 133-154. [Link]

Abrahams, L., Pancorbo, G., Primi, R., Santos, D., Kyllonen, P., John, O. P., \& De Fruyt, F. (2019). Social-emotional skill assessment in children and adolescents: Advances and challenges in personality, clinical, and educational contexts. Psychological Assessment, 31(4), 460. [Link]

Brady, M. (2011). Researching governmentalities through ethnography: the case of Australian welfare reforms and programs for single parents. Critical Policy Studies, 5(3), 264-282. [Link]

Beirami, M., Hashemi, T., Mirnasab, M., Kolyaei, L. (2018). Effectiveness of Social Problem-Solving Training on the Components of Social competence in Students Victim of Bullying. Social Cognition, 7(1), 53-74. (Persian). [Link]

Banerjee, P. A. (2016). A systematic review of factors linked to poor academic performance of disadvantaged students in science and maths in schools. Cogent Education, 3(1), 1178441. [Link]

Collings, S., Jenkin, G., Carter, K., \& Signal, L. (2014). Gender differences in the mental health of single parents: New Zealand evidence from a household panel survey. Social psychiatry and psychiatric epidemiology, 49(5), 811-821. [Link]

D'Zurilla, T. J., Nezu, A. M., \& Maydeu-Olivares, A. (2002). Social problem-solving inventory-revised. [Link]

Erozkan, A. (2013). The effect of communication skills and interpersonal problem-solving skills on social self-efficacy. Educational Sciences: Theory and Practice, 13(2), 739-745. [Link]

Fransson, E., Låftman, S. B., Östberg, V., \& Bergström, M. (2018). Wellbeing among children with single parents in Sweden: Focusing on shared residence. The triple bind of single-parent families: Resources, employment and policies to improve well-being, 145-167. [Link]
Felner, R. D., Lease, A. M., \& Phillips, R. S. C. (1990). Social competence and the language of adequacy as a subject matter for psychology: A quadripartite trilevel framework. The development of social competence in adolescence, 245-264. [Link]

Ghadiry, F, Shahrbanoo, A, Aghamohammadian Sharbaf, H. (2020). The Effectiveness of Social-Emotional Skills Training on Resilience and Adjustment of Male Adolescent Students in Boarding Schools. Studies in Learning \& Instruction, 11(2), 71-87. (Persian). [Link]

Gooding, L. F. (2011). The effect of a music therapy social skills training program on improving social competence in children and adolescents with social skills deficits. Journal of music therapy, 48(4), 440462. [Link]

Hukom, K., \& Madrigal, D. (2020). Assessing the Correlation between Demographics, Academic Stress, and Coping Strategies of Filipino High School Students with Single-Parents. Philippine Social Science Journal, 3(3), 151-161. [Link]

Hosokawa, R., \& Katsura, T. (2017). A longitudinal study of socioeconomic status, family processes, and child adjustment from preschool until early elementary school: the role of social competence. Child and adolescent psychiatry and mental health, 11(1), 1-28. [Link]

Hosaini, H. (2019). The Effect of Teaching SocialEmotional Skills on Subjective Well-being and Academic Adaptability of Students. journal of motor and behavioral sciences, 2(1), 1-9. (Persian). [Link]

Jones, D. E., Greenberg, M., \& Crowley, M. (2015). Early social-emotional functioning and public health: The relationship between kindergarten social competence and future wellness. American journal of public health, 105(11), 2283-2290. [Link]

Janusz, J. A., Kirkwood, M. W., Yeates, K. O., \& Taylor, H. G. (2002). Social problem-solving skills in children with traumatic brain injury: Long-term outcomes and prediction of social competence. Child Neuropsychology, 8(3), 179-194. [Link]

Klassen, A. F., Gulati, S., Granek, L., Rosenberg-Yunger, Z. R., Watt, L., Sung, L., ... \& Shaw, N. T. (2012). Understanding the health impact of caregiving: a qualitative study of immigrant parents and single parents of children with cancer. Quality of Life Research, 21(9), 1595-1605. [Link]

Kakabraee, K., Seidy, M. (2019). The Effectiveness of Interpersonal Problem-Solving Skills Training on Social Problems of Preschool Students. Journal of 
Applied Psychological Research, 9(4), 159-175. (Persian). [Link]

Kesner, J. E., \& McKenry, P. C. (2001). Single parenthood and social competence in children of color. Families in Society, 82(2), 136-144. [Link]

Lafavor, T. (2018). Predictors of academic success in 9-to 11-year-old homeless children: The role of executive function, social competence, and emotional control. The Journal of Early Adolescence, 38(9), 1236-1264. [Link]

Leidy, M. S., Guerra, N. G., \& Toro, R. I. (2010). Positive parenting, family cohesion, and child social competence among immigrant Latino families. Journal of Family Psychology, 24(3), 252. [Link]

McKown, C., Gumbiner, L. M., Russo, N. M., \& Lipton, M. (2009). Social-emotional learning skill, selfregulation, and social competence in typically developing and clinic-referred children. Journal of Clinical Child \& Adolescent Psychology, 38(6), 858-871. [Link]

Mefoh, P. C., Nwoke, M. B., Chukwuorji, J. C., \& Chijioke, A. O. (2017). Effect of cognitive style and gender on adolescents' problem-solving ability. Thinking Skills and Creativity, 25, 47-52. [Link]

Montazer, N., Dosti, Y., Hassanzadeh, R. (2020). The Compare to Effect of Emotional Competence and Problem-Solving Training on Distress Tolerance among Students from Farhangian University. Biquarterly Journal of Cognitive Strategies in Learning, 7(13), 149-172. (Persian). [Link]

Malouff, J. M., Thorsteinsson, E. B., \& Schutte, N. S. (2007). The efficacy of problem-solving therapy in reducing mental and physical health problems: a meta-analysis. Clinical psychology review, 27(1), 46-57. [Link]

McDowell, D. J., \& Parke, R. D. (2005). Parental control and affect as predictors of children's display rule use and social competence with peers. Social Development, 14(3), 440-457. [Link]

Montazer, N., Dosti, Y., Hassanzadeh, R. (2020). The Compare to Effect of Emotional Competence and Problem-Solving Training on Distress Tolerance among Students from Farhangian University. Biquarterly Journal of Cognitive Strategies in Learning, 7(13), 149-172. (Persian). [Link]

Nawaz, S., Ali, U., Najmussaqib, A., Ahmed, M., \& Rehna, T. (2019). The relationship between parental rejection and social skills among children of single parents. European Online Journal of Natural and Social Sciences: Proceedings, 8(2),195. [Link]
Panula, V., Junttila, N., Aromaa, M., Rautava, P., \& Räihä, H. (2020). Parental Psychosocial Well-Being as a Predictor of the Social Competence of a Child. Journal of Child and Family Studies, 29(11), 30043019. [Link]

Reid, M. J., Webster-Stratton, C., \& Hammond, M. (2007). Enhancing a classroom social competence and problem-solving curriculum by offering parent training to families of moderate-to high-risk elementary school children. Journal of Clinical Child and Adolescent Psychology, 36(4), 605-620. [Link]

Stack, R. J., \& Meredith, A. (2018). The impact of financial hardship on single parents: An exploration of the journey from social distress to seeking help. Journal of family and economic issues, 39(2), 233242. [Link]

Sadri Damirchi S, Navidi A, Porshneh K. (2009). Social emotional skills teaching. Tehran: Mahabad Islamic Azad University. (Persian). [Link]

Sani, H. K., Mohammadzadeh, H., Jahangirimehr, A., Kamboo, M. S., \& Pour, A. S. (2017). Surveying the Relationship between Addiction to Social Networks and Emotional Maturity in Students. Int J Environ Sci Educ, 12(2), 311-20. [Link]

Stewart, E., Catroppa, C., Gill, D., Webster, R., Lawson, J., Mandalis, A., ... \& Lah, S. (2018). Theory of mind and social competence in children and adolescents with genetic generalised epilepsy (GGE): relationships to epilepsy severity and antiepileptic drugs. Seizure, 60, 96-104. [Link]

Tlustos, S. J., Kirkwood, M. W., Taylor, H. G., Stancin, T., Brown, T. M., \& Wade, S. L. (2016). A randomized problem-solving trial for adolescent brain injury: Changes in social competence. Rehabilitation psychology, 61(4), 347. [Link]

Van Gasse, D., \& Mortelmans, D. (2020). With or Without You-Starting Single-parent Families: A Qualitative Study on How Single Parents by Choice Reorganise Their Lives to Facilitate Single Parenthood from a Life Course Perspective. Journal of Family Issues, 41(11), 2223-2248. [Link] 